\title{
EMOCIONALNA INTELIGENCIJA DAROVITIH UČENIKA ${ }^{* * *}$
}

Polazeći od savremenog shvatanja darovitosti kao domenospecifičnog kvaliteta, sprovedeno je istraživanje sa ciljem da se utvrde distinktivne karakteristike učenika darovitih u domenu muzike, slikarstva, sporta i matematike, u prostoru sledećih aspekata emocionalne inteligencije: samosvest, vladanje samim sobom, društvena svest i upravljanje odnosima. Na prigodnom uzorku od 473 ispitanika, koji pohađaju specijalizovane srednje škole za darovite iz Novog Sada, Beograda i Kraljeva, primenjena je skala emocionalnih kompetencija, konstruisana za potrebe ovog istraživanja. Nakon ispitivanja razlika između četiri grupe ispitanika pronađena su dva distinktivna obeležja u setu specifikovanih aspekata emocionalne inteligencije, a to su: vladanje samim sobom i samosvest. Dobijeni nalazi sugerišu da grupa sportski darovitih učenika prednjači u pogledu razvijenosti vladanja samim sobom, te da se po ovom svojstvu statistički značajno razlikuje od likovno i matematički darovitih ispitanika. Kada je u pitanju samosvest, uočljivo je da se likovno daroviti učenici statistički značajno razlikuju od preostale tri grupe ispitanika, te da je ovo svojstvo kod njih najmanje izraženo. Ovakvi rezultati upućuju na značaj domena u nastanku specifične konstelacije emocionalnih kompetencija koja se u njemu manifestuje. Stoga se zaključuje se da se emocionalno funkcionisanje darovitih može precizno sagledati jedino ako se locira u okvire pojedinačnih domena.

Ključne reči: vanintelektualne karakteristike, domeni darovitosti, samosvest, vladanje samim sobom, društvena svest, upravljanje odnosima.

\section{UVOD}

Za razliku od nekadašnjeg izjednačavanja darovitosti sa visokom opštom inteligencijom (Terman, 1925), koje je rezultiralo unidimenzionalnim poimanjem ovog fenomena, savremene koncepcije razlažu darovitost na veći broj komponenti, pri čemu su intelektualne sposobnosti ukomponovane u složaj raznovrsnih

\footnotetext{
*milenaletic@ff.uns.ac.rs

** Rad je nastao kao rezultat rada na projektu „Kvalitet obrazovnog sistema Srbije u evropskoj perspektivi”, br. 179010 (2011-2017), čiju realizaciju finansira Ministarstvo prosvete, nauke i tehnološkog razvoja Republike Srbije. U radu su korišćeni rezultati doktorske disertacije „Značaj moralnih i liderskih svojstava za ostvarenje darovitosti” odbranjene na Filozofskom fakultetu Univerziteta u Novom Sadu.
} 
vanintelektualnih karakteristika, koji se u celini uzima kao podloga darovitosti (Gagné, 2005; Heller, Perleth \& Lim, 2005). Drugim rečima, savremeno viđenje inteligenciju kvalifikuje kao nužan, ali ne i dovoljan uslov razumevanja prirode darovitosti, koji, prema tome, značajan eksplikativni doprinos ostvaruje tek u konstelaciji sa vanintelektualnim karakteristikama (Pekić, 2011). Shodno tome, darovitost se dovodi u relaciju sa: intenzivnom motivacijom, koja podrazumeva izraženu radoznalost, jak motiv postignuća, snažnu istrajnost u ostvarivanju ciljeva (Csikszentmihalyi, Rathunde \& Whalen, 1997); visokim stepenom nezavisnosti, kako u socijalnom, tako i u intelektualno-moralnom smislu (Franks \& Dolan, 1982; Winner, 1996); povišenom osetljivosti tj. natprosečnim intenzitetom mentalne i emocionalne aktivnosti (Piechowski \& Miller, 1995) i sl. Reč je o tome da vanintelektualne karakteristike pospešuju intelektualno funkcionisanje osobe i usmeravaju je da svoj potencijal za darovitost pretoči u socijalno konstruktivnu akciju.

Uvođenjem vanintelektualnih karakteristika proširuje se koncept darovitosti izvan granica opšte inteligencije radi fokusiranja na razvijanje talenata (Csikszentmihalyi et al., 1997; Gagne, 2005), ali se istovremeno uvodi ideja da pojedine vanintelektualne karakteristike, same po sebi, predstavljaju zasebne modalitete darovitosti ili inteligencije. Takve su, na primer, emocionalna inteligencija (Goleman, 1995), interpersonalna i intrapersonalna inteligencija (Gardner, 1999), mudrost (Sternberg, 2000) i sl. Treba, međutim, naglasiti da pomenute karakteristike nisu potpuno „vanintelektualne”. Svaka od njih poseduje neku intelektualnu komponentu i uključuje određen nivo intelektualnih sposobnosti (Lee \& Olszewski-Kubilius, 2006).

\section{Emocionalna inteligencija i slični koncepti}

Pojam emocionalna inteligencija uveli su psiholozi Salovej i Majer (Salvoley \& Mayer, 1990) početkom devedesetih godina prošlog veka, definišući ga kao skup mentalnih sposobnosti povezanih sa emocijama i sa obradom emocionalnih informacija koje pospešuju logičko razmišljanje i inteligenciju, te su njen sastavni deo. Ovi autori smatraju da se navedene sposobnosti razvijaju sa godinama i sa iskustvom, pa veruju da su one nezavisne od osobina i talenata i od prevladavajućeg načina razmišljanja (Mayer \& Salvoley, 1993). Prema Majeru i Saloveju (1997) postoje četiri glavne sposobnosti kojima se emocionalna inteligencija realizuje, a to su: opažanje emocija, njihovo izražavanje, emocionalna facilitacija ili korišćenje emocija i upravljanje emocijama. Pomenute sposobnosti trebalo bi da doprinesu tačnoj proceni, razlikovanju i izučavanju vlastitih emocija, a 
isto tako i proceni tuđih emocija i upotrebi emocija u planiranju i ostvarivanju ciljeva u životu (Ilić, 2008).

Iako su najzaslužniji za naučno vrednovanje samog tog pojma, Salovej i Majer nisu uspeli da popularizuju emocionalnu inteligenciju. Ona je svoju afirmaciju u javnosti doživela tek pošto je Danijel Goleman 1995. godine objavio knjigu Emocionalna inteligencija - zašto je važnija od kvocijenta inteligencije (Emotional intelligence: Why it can matter more than $I Q$ ). Sintetizujući dotadašnja saznanja o tzv. mekim veštinama i proširujući Salovejov i Majerov model sposobnosti, Goleman je ponudio integrisani koncept matrice od ukupno osamnaest emocionalnih kompetencija (Goleman, Bojacis, Maki, 2006), koje je svrstao u četiri domena - samosvest, vladanje samim sobom, društvena svest i upravljanje odnosima, koje je potom podelio u dve velike grupe: lična kompetencija (upravljanje sobom) i društvena kompetencija (upravljanje drugima).

Samosvest, duboko razumevanje sopstvenih osećanja, potreba, namera, vrednosti i slabosti, predstavlja temelj celokupne emocionalne inteligencije. Ona obuhvata tri karakteristike, a to su emocionalna samosvest, tačno ocenjivanje samog sebe i samopouzdanje. Vladanje samim sobom ne dozvoljava ljudima da ih štetne, uznemirujuće emocije, kao što su tuga, strepnja ili bes, izbace iz koloseka. Osobe koje uspešno vladaju sobom i svojim negativnim emocijama, uspevaju da i u najtežim situacijama sačuvaju prisustvo duha, dobro raspoloženje i entuzijazam. Karakteristike ove sposobnosti su: samokontrola, transparentnost, prilagodljivost, težnja za uspehom, inicijativa i optimizam. Pored svesti o sebi i upravljanja vlastitim emocijama, emocionalna inteligencija podrazumeva i razvijenu društvenu svest i sve njene komponente, a pre svega, empatiju, zatim svest o organizaciji, te predusretljivost. Četvrta oblast emocionalne inteligencije, u kojoj se sustižu prethodne tri, jeste upravljanje odnosima. Ovaj domen obuhvata: inspiraciju, uticaj, usavršavanje drugih ljudi, katalizator promene, upravljanje sukobima i timski rad i saradnju (Goleman i dr., 2006).

Iako je model kompetencija logičan nastavak u razvoju teorija o emocionalnoj inteligenciji i predstavlja aplikaciju tog konstrukta u praksi, među naučnicima priklonjenim Salovejevom i Majerovom modelu sposobnosti (Caruso, Mayer \& Salovey, 2002) i Golemanovom modelu kompetencija (McClelland, 1998) vodi se snažna polemika o obuhvatnosti tog konstrukta. Naučnici priklonjeni modelu sposobnosti prigovaraju Golemanu zbog uključivanja u definiciju emocionalne inteligencije i elemenata poput inicijative, optimizma i težnje ka uspehu, što su po njima više faktori ličnosti, pa kako ističu Majer i Salovej (1997), nemaju veze sa emocionalnom inteligencijom, dok ih Goleman (1998) smatra 
nerazdvojnim elementima emocionalne inteligencije, usko povezanim sa načinom na koji pojedinac upravlja svojim emocijama.

Premda su razvijeni brojni instrumenti za merenje emocionalne inteligencije, ne postoji opšteprihvaćen instrument, a rezultati dobijeni primenom različitih instrumenata zbog različitih varijabli uključenih u pojedine instrumente, ali i zbog drugačijih pristupa proceni emocionalne inteligencije, nisu u potpunosti uporedivi, pa je to glavna zamerka kritičara konstrukta emocionalne inteligencije. Međutim, ako se zna da je emocionalna inteligencija dinamička kategorija, tada se čini ispravnim prihvatiti tezu pojedinih autora (Palmer, Walls, Burgess \& Stough, 2001; Gardner \& Stough, 2002) da bi emocionalnu inteligenciju trebalo shvatati kontekstualno, te da bi njena obuhvatnost trebalo da zavisi od okolnosti u skladu sa kojima će se značenje verovatno i dalje razvijati i nadograđivati tokom vremena. Zbog toga se nastojanje ka unificiranju instrumenta za merenje emocionalne inteligencije ne čini opravdanim, pa ni nedostatak takvog, jedinstvenog instrumenta ne predstavlja pravi argument zbog kojeg emocionalnu inteligenciju ne bi trebalo prihvatiti kao dovoljno naučnu (Ilić, 2008).

$\mathrm{Ni}$ autori iz oblasti darovitosti nisu ostali imuni na domen emocionalne inteligencije, o čemu svedoče brojni koncepti i modeli koji su slični emocionalnoj inteligenciji ili se na nju odnose. Jedan takav koncept, uveo je poljski psiholog Dabrovski (Dabrowski \& Piechowski, 1977), a razradio Pijehovski (Piechowski, 1979) sa saradnicima (Piechowski \& Colangelo, 1984; Piechowski \& Miller, 1995). Koncept psihičke preosetljivosti, kako ga je Dabrovski nazvao, javlja se u pet modaliteta: psihomotornom, čulnom, intelektualnom, imaginativnom i emocionalnom (Piechowski \& Colangelo, 1984; Piechowski \& Miller, 1995). Preosetljivost ili „povišena osetljivost” u tumačenju ovih autora ima pozitivnu konotaciju i podrazumeva ,povišeno doživljavanje koje doprinosi razvojnom potencijalu darovitih" (Altaras, 2006: 41). Mejer i saradnici (Mayer, Perkins, Caruso \& Salovey, 2001) artikulisali su vezu između emocionalne preosetljivosti i emocionalne inteligencije kroz činjenicu da oba koncepta obuhvataju svest o osećanjima, kao i njihovo razumevanje i kontrolisanje.

Pre nego što je devedesetih godina prošlog veka emocionalna inteligencija postala popularna, Gardner (1983) je utvrdio postojanje sedam različitih inteligencija, dozvolivši mogućnost menjanja njihovog broja. Reč je o sledećim vrstama inteligencije: lingvistička, muzička, logičko-matematička, prostorna (spacijalna), telesno-kinestetička, interpersonalna i intrapersonalna. Poslednje dve, tzv. personalne inteligencije, predstavljaju sposobnost efikasne interakcije sa drugim ljudima putem razumevanja njihovih osećanja, emocija, namera i motiva, kao i sposobnost regulisanja sopstvenog života putem preciznog razumevanja 
sopstvenih emocija i sposobnosti. Gardner (1999) je, poput mnogih (npr. Mayer et al., 2001), shvatio da su personalne inteligencije slične Golemanovoj (1995) emocionalnoj inteligenciji po tome što su sve tri vezane za poznavanje, svest i kontrolu sopstvenih i tuđih osećanja, kao i za empatiju i osetljivost na emocionalna stanja (Lee \& Olszewski-Kubilius, 2006).

Kao domen darovitosti, Sternberg (2000) naznačava mudrost, koja je koncipirana kao posrednik između inteligencije i kreativnosti, sa jedne strane, i ostvarivanja opšte dobrobiti kroz vlastita postignuća, sa druge strane. Preciznije rečeno, opšta dobrobit se realizuje kroz izbalansiranost intrapersonalnih (vlastiti interesi), interpersonalnih (interesi drugih osoba) i ekstrapersonalnih interesa (interesi zajednice, grada, države itd.), čime se postiže i sklad između adaptacije (menjanje sebe u skladu sa zahtevima sredine), oblikovanja (pojedinac menja sredinu prema vlastitim potrebama) i selekcije okruženja (izbor nove, podesnije sredine). U slučaju da inteligencija i kreativnost nemaju utemeljenje u mudrosti, stvaralaštvo se oglušuje o imperativ opšte dobrobiti i stavlja u funkciju ostvarivanja „intrapersonalnih” interesa (Pekić, 2011). Mudrost je slična emocionalnoj inteligenciji po tome što uključuje skriveno znanje o sebi i drugima, ali je slična i praktičnoj inteligenciji jer se odnosi samo na kontekst svakodnevnog života pojedinca (Lee \& Olszewski-Kubilius, 2006).

\section{Pregled relevantnih istraživanja}

Emocionalni život darovitih pojedinaca oduvek je otvarao širok dijapazon pitanja koja i danas zaokupljaju pažnju naučne javnosti. Jedno od njih glasi: da li darovitost podrazumeva smetnje u emocionalnom i socijalnom funkcionisanju ili, pak, nosi oznaku superiornosti u naznačenim aspektima? U pionirskom istraživanju ove problematike, Terman (1925) je došao do zaključka da daroviti pojedinci ne ispoljavaju superiornost samo u pogledu mentalnih sposobnosti, odnosno aspekata koji se direktno oslanjaju na inteligenciju (školsko postignuće, interesovanja, profesionalna uspešnost), već i u pogledu mnogih karakteristika koje nisu u neposrednoj vezi sa inteligencijom. Njegovi nalazi sugerišu da su daroviti ispitanici boljeg fizičkog zdravlja, napredniji u domenu fizičkog i motornog razvoja, emocionalno stabilniji, socijalno adaptabilniji, manje skloni antisocijalnom ponašanju, napredniji u pogledu moralnog rezonovanja i sl. (Terman, 1922, prema: Winner, 1996). Zbog ovakvih nalaza, Termanu se pripisuje zasluga za uspostavljanje „načela korelacije” u tumačenju odnosa visokih sposobnosti i vanintelektualnih aspekata razvoja darovitih (Stojaković, 2001, prema: Pekić, 2011). Međutim, neka kasnija istraživanja sugerišu da relacija između intelektualne 
darovitosti i statusa u vanintelektualnim aspektima nije jednoznačna kao što je to Terman tvrdio, te da odgovor na gore postavljeno pitanje prevashodno zavisi od intelektualnog nivoa darovitog pojedinca (Pekić, 2011). Naime, u slučaju „umerene" intelektualne darovitosti, ustanovljen je „socijalno optimalan” nivo inteligencije, da bi slučajevi ,izrazite” intelektualne darovitosti, bili prepoznati kao korelati socijalne izolacije (Hollingworth, 1942, prema: Winner, 1996). Mnoga savremena istraživanja potvrdila su ove nalaze (Gross, 1993, Maas, 1992, Tannenbaum, 1983, svi prema: Norman, Ramsay, Martray \& Roberts, 1999).

Premda postoje istraživanja koja pokazuju da profil darovitih na merama preosetljivosti dosledno odstupa od norme, u većini studija kao diskriminativni su se pokazali određeni, ali ne svi oblici preosetljivosti (Altaras, 2006). Najčešći nalaz je da daroviti ispitanici imaju više skorove na merama emocionalne, intelektualne i imaginativne preosetljivosti (Piechowski \& Colangelo, 1984; Bouchet \& Falk, 2001). Ove varijacije u nalazima, međutim, ne dovode u pitanje osnovnu tezu da daroviti poseduju određene karakteristike koje predstavljaju manifestacije povišene osetljivosti.

Distinktivna obeležja darovitih iz emocionalne sfere najčešće su utvrđivana u odnosu na prosečnu populaciju. Znatno ređe se, međutim, nailazi na deskripciju emocionalne strane ličnosti u zavisnosti od specifičnog domena manifestovanja darovitosti. Ovo je značajno zbog uvreženog shvatanja darovitosti kao domenospecifičnog kvaliteta, koji se ne ogleda samo u razvijenosti određenih vrsta sposobnosti već i u različitim kombinacijama vansposobnosnih karakteristika (Benbow \& Minor, 1990, prema: Pekić, 2010). Ukoliko se zapitamo o tome da li se daroviti u različitim domenima uzajamno razlikuju u emocionalnom funkcionisanju, naći ćemo se na terenu spekulativnog. Upravo zbog toga, ovo istraživanje pretenduje na to da rasvetli pitanje razlika u razvijenosti emocionalne inteligencije $\mathrm{u}$ kontekstu različitih vidova darovitosti, te da ovu problematiku prevede sa terena spekulacije na teren empirije (Letić, 2015).

\section{METODOLOGIJA ISTRAŽIVANJA}

\section{Cilj istraživanja}

Ovaj rad imao je za cilj da utvrdi distinktivna obeležja učenika darovitih u domenu muzike, slikarstva, sporta i matematike, u prostoru sledećih aspekata emocionalne inteligencije: samosvest, vladanje samim sobom, društvena svest i upravljanje odnosima. 
Varijable

Istraživanjem su obuhvaćene sledeće varijable:

Darovitost, shvaćena kao natprosečna razvijenost specifičnih sposobnosti ovladavanja određenim domenom (muzika, slikarstvo, sport, matematika). Ovakvo shvatanje darovitosti korespondira sa teorijskim koncepcijama, odnosno empirijskim nalazima koji sugerišu da je darovitost najopravdanije operacionalizovati preko visokog postignuća na testovima specifičnih sposobnosti (Gagné, 1997; Robinson, 2005). S obzirom na to da istraživanje obuhvata učenike specijalizovanih srednjih škola za darovite, moglo bi se reći da prijemni ispiti za ove škole podrazumevaju primenu testova specifičnih sposobnosti, te da propisani minimum bodova neophodan za upis, zapravo, znači da kandidati moraju imati razvijenije specifične sposobnosti u odnosu na prosečnu populaciju.

Emocionalna inteligencija, postulirana u okviru Golemanovog integrisanog modela koji pretpostavlja da se prostor emocionalne inteligencije može opisati duž sledeća četiri široka domena - samosvest, vladanje samim sobom, društvena svest i upravljanje odnosima (Goleman i dr., 2006). Ono što je podstaklo izbor ovog teorijskog modela jeste njegova konceptualna obuhvatnost, te zapažanje da se $\mathrm{u}$ savremenoj literaturi gotovo ne mogu pronaći nalazi koji elaboriraju problematiku darovitosti iz perspektive ovog teorijskog modela.

\section{Instrument}

Činjenica da ne postoji opšteprihvaćen instrument za merenje emocionalne inteligencije, te zapažanje pojedinih autora (Palmer et al., 2001; Gardner \& Sough, 2002) da je emocionalna inteligencija dinamička kategorija koju bi trebalo shvatati kontekstualno, bili su u osnovi naše motivacije da sačinimo novi instrument za merenje ovog konstrukta. Pri konstrukciji i definisanju ajtema pošli smo od Golemanovog određenja emocionalne inteligencije.

$\mathrm{U}$ cilju ispitivanja prostora merenja skale emocionalnih kompetencija, primenjena je faktorska analiza. Provera opravdanosti primene faktorskre analize izvršena je preko Kajzer-Mejer-Oklinovog (KMO) pokazatelja adekvatnosti uzorka i Bartletovog testa sferičnosti. Dobijena vrednost KMO iznosila je .905, dok je vrednost Bartletovog testa sferičnosti bila statistički značajna $(\mathrm{p}=.000)$, što ukazuje na prikladnost korelacijske matrice za faktorsku analizu. Nakon eliminacije psihometrijski loših ajtema u finalnom rešenju je zadržan 51 ajtem. Na osnovu scree-testa izolovana su četiri faktora koja objašnjavaju 32,87\% zajedničke 
varijanse ulaznog skupa varijabli (Tabela 1). Kronbahova alfa iznosi .933, što znači da je pouzdanost instrumenta vrlo visoka.

Tabela 1. Vrednosti karakterističnih korenova i procenat objašnjene varijanse izolovanih faktora skale emocionalnih kompetencija

\begin{tabular}{lcccc}
\hline Faktor & \multicolumn{3}{c}{ Inicijalne vrednosti } & Vrednosti nakon rotacije \\
\hline & $\lambda$ & $\begin{array}{c}\% \\
\text { varijanse }\end{array}$ & $\begin{array}{c}\text { Kumulativni } \\
\%\end{array}$ & $\lambda$ \\
1 & 17.93 & 19.92 & 19.92 & 14.38 \\
2 & 4.59 & 5.10 & 25.09 & 11.68 \\
3 & 3.62 & 4.02 & 29.04 & 9.52 \\
4 & 3.45 & 3.83 & 32.87 & 9.77 \\
\hline
\end{tabular}

Prvi faktor okuplja ajteme koji se odnose na sposobnost artikulisanja zajedničke vizije, na sposobnost efikasnog rešavanja konflikata, kao i na sposobnost timskog rada i saradnje. Taj je faktor stoga nazvan upravljanje odnosima $(\alpha=89)$. Drugi faktor okuplja ajteme koji se odnose na empatiju, svest o grupi i predusretljivost. Ovaj je faktor nazvan društvena svest $(\alpha=.86)$. Treći faktor okuplja ajteme koji se odnose na sposobnost samokontrole, na sposobnost adaptacije na nove i nepredviđene situacije, kao i na uspešno prevazilaženje teškoća. Taj je faktor nazvan vladanje samim sobom $(\alpha=.80)$. Četvrti faktor zasićen je stavkama koje ukazuju na tendenciju osobe ka dubokom razumevanju sopstvenih osećanja, potreba, namera, vrednosti i slabosti. Ovaj je faktor nazvan samosvest $(\alpha=.71)$.

$\mathrm{Na}$ osnovu matrice strukture izolovanih faktora, odnosno sadržaja stavki koje sa izolovanim faktorima ostvaruju najviše korelacije, potvrđena je operacionalizacija konstrukta emocionalne inteligencije od koje se krenulo u konstrukciji upitnika.

Uzorak

Uzorak je prigodan, ali je način uzorkovanja sadržavao i elemente stratifikovanog uzorka, budući da se obavila njegova stratifikacija prema domenu darovitosti (muzika, slikarstvo, sport, matematika). U okviru četiri stratuma pristupilo se primeni upitnika kojima je ispitano ukupno 473 učenika specijalizovanih srednjih škola za darovite iz Novog Sada, Beograda i Kraljeva. Struktura uzorka, te njegova ujednačenost $u$ pogledu relevantnih varijabli vidljiva je iz Tabele 2. 
Tabela 2. Struktura uzorka

\begin{tabular}{clcc}
\hline \multicolumn{2}{c}{ Varijable } & Frekvencije & Procenat \\
\hline \multirow{6}{*}{ Domen darovitosti } & Muzika & 102 & 21.6 \\
& Slikarstvo & 96 & 20.3 \\
& Sport & 152 & 32.1 \\
& Matematika & 123 & 26.0 \\
& Muški & 206 & 43.6 \\
& Ženski & 267 & 56.4 \\
& 15 godina & 98 & 20.7 \\
& 16 godina & 131 & 27.7 \\
& 17 godina & 115 & 24.3 \\
& 18 godina & 92 & 19.5 \\
& 19 godina & 37 & 7.8 \\
\cline { 2 - 4 } & Ukupno & 473 & 100.0 \\
\hline
\end{tabular}

\section{REZULTATI I DISKUSIJA}

Razlike u aspektima emocionalne inteligencije s obzirom na domen darovitosti

U realizaciji specifikovanog cilja istraživanja primenjen je postupak multivarijantne analize varijanse. Rezultati testiranja značajnosti razlika $u$ aspektima emocionalne inteligencije, s obzirom na pripadnost jednoj od pomenutih subpopulacija, prikazani su u Tabeli 3 .

Tabela 3. Multivarijantni testovi značajnosti razlika

\begin{tabular}{cccc}
\hline Multivarijantni testovi & Vrednost & F & p \\
\hline Pillai's Trace & .518 & 7.376 & $\mathbf{. 0 0 0}$ \\
Wilks' Lambda & .535 & 8.166 & $\mathbf{. 0 0 0}$ \\
Hotelling's Trace & .772 & 9.018 & $\mathbf{. 0 0 0}$ \\
Roy's Largest Root & .627 & $22.139(\mathrm{~b})$ & $\mathbf{. 0 0 0}$ \\
\hline
\end{tabular}

Očitavanjem relevantnih vrednosti iz gornje tabele konstatuje se postojanje statistički značajnih razlika u linearnoj kombinaciji zavisnih promenljivih, $s$ obzirom na tip darovitosti. No, kako ovim ostajemo uskraćeni za podatak o pojedinačnim aspektima emocionalne inteligencije u kojima se ispitivane grupe razlikuju, obavljena su naknadna poređenja među grupama. 
Tabela 4. Značajnost razlika među grupama na pojedinačnim zavisnim varijablama

\begin{tabular}{|c|c|c|c|c|c|c|}
\hline $\begin{array}{c}\text { Zavisne } \\
\text { varijable }\end{array}$ & $\begin{array}{c}\text { Grupišuća } \\
\text { varijabla }\end{array}$ & A.S. & S.D. & df & $\mathrm{F}$ & $\mathrm{p}$ \\
\hline \multirow{4}{*}{$\begin{array}{l}\text { Upravljanje } \\
\text { odnosima }\end{array}$} & Muzika & .063 & .996 & 3 & .687 & .561 \\
\hline & Slikarstvo & -.125 & 1.057 & & & \\
\hline & Sport & .025 & .907 & & & \\
\hline & Matematika & .009 & 1.034 & & & \\
\hline \multirow[t]{4}{*}{ Društvena svest } & Muzika & .010 & 1.089 & 3 & 1.894 & .130 \\
\hline & Slikarstvo & -.064 & .996 & & & \\
\hline & Sport & .161 & .840 & & & \\
\hline & Matematika & -.098 & 1.013 & & & \\
\hline \multirow{4}{*}{$\begin{array}{c}\text { Vladanje } \\
\text { samim sobom }\end{array}$} & Muzika & -.057 & .992 & 3 & 4.591 & .004 \\
\hline & Slikarstvo & -.151 & 1.000 & & & \\
\hline & Sport & .243 & .912 & & & \\
\hline & Matematika & -.120 & 1.037 & & & \\
\hline \multirow[t]{4}{*}{ Samosvest } & Muzika & .151 & .885 & 3 & 6.165 & .000 \\
\hline & Slikarstvo & -.359 & 1.072 & & & \\
\hline & Sport & .129 & .989 & & & \\
\hline & Matematika & .055 & .936 & & & \\
\hline
\end{tabular}

$\mathrm{Na}$ osnovu značajnosti $\mathrm{F}$ testa moguće je zaključiti da se učenici daroviti $\mathrm{u}$ različitim domenima uzajamno razlikuju na faktorima vladanje samim sobom $(\mathrm{p}=.004)$ i samosvest $(\mathrm{p}=.000)$. Iz Tabele 4 uočljivo je da grupa sportski darovitih učenika prednjači u pogledu razvijenosti vladanja samim sobom, dok je samosvest najizraženija kod muzički darovitih ispitanika. No, da bi se precizno utvrdilo između kojih grupa postoje razlike (pošto nezavisna promenljiva ima četiri nivoa), urađene su dve univarijantne analize varijanse, sa testovima za naknadna poređenja među grupama.

Prva od njih, koja je imala za cilj utvrđivanje razlika između četiri grupe ispitanika u pogledu razvijenosti vladanja samim sobom (Tabela 5), jasno ukazuje da je ovo svojstvo izraženije kod sportski darovitih učenika nego kod njihovih likovno i matematički darovitih vršnjaka, te da se po njemu pomenute grupe ispitanika statistički značajno razlikuju. 
Tabela 5. Scheffe-ov test višestrukih poređenja među grupama (vladanje samim sobom)

\begin{tabular}{cccc}
\hline $\begin{array}{c}\text { (I) } \\
\text { Domen darovitosti }\end{array}$ & $\begin{array}{c}(\mathrm{J}) \\
\text { Domen darovitosti }\end{array}$ & $\begin{array}{c}\text { Razlika između } \\
\text { aritmetičkih sredina } \\
\text { I-J }\end{array}$ & $\mathrm{p}$ \\
\hline Muzika & Slikarstvo & .093 & .930 \\
& Sport & -.300 & .128 \\
Slikarstvo & Matematika & .063 & .973 \\
& Muzika & -.093 & .930 \\
& Sport & $-.393\left(^{*}\right)$ &. $\mathbf{0 2 5}$ \\
Sport & Matematika & -.030 & .997 \\
& Muzika & .300 & .128 \\
Matematika & Slikarstvo & $.393\left(^{*}\right)$ &. $\mathbf{0 2 5}$ \\
& Matematika & $.363\left(^{*}\right)$ & $\mathbf{. 0 2 6}$ \\
& Muzika & -.063 & .973 \\
& Slikarstvo & .030 & .997 \\
& Sport & $-.363\left(^{*}\right)$ & $\mathbf{. 0 2 6}$ \\
\hline
\end{tabular}

Vladanje samim sobom najbolje opisuju ajtemi: „ne dozvoljavam da me štetne, uznemirujuće emocije, kao što su tuga, strepnja ili bes, izbace iz koloseka"; „uspevam da i u najtežim situacijama sačuvam prisustvo duha, dobro raspoloženje i entuzijazam”; ,ostajem miran/na i bistre glave i kada sam pod velikim pritiskom ili opterećen/na problemima". Specifičnije, učenici daroviti u domenu sporta se, u poređenju sa učenicima darovitim u domenima slikarstva i matematike, mogu opisati kao osobe koje poseduju veći nivo samokontrole (obuzdavanje burnih osećanja i poriva), transparentnosti (ispoljavanje poštenja, integriteta, pouzdanosti), prilagodljivosti (fleksibilno prilagođavanje novim situacijama ili prevazilaženje prepreka), težnje za uspehom (poriv da se kroz usavršavanje dostignu lični standardi izvrsnosti), inicijative (spremnost da se deluje i iskoristi prilika), kao i optimizma (pozitivno sagledavanje događaja). Ovakvi nalazi mogli bi se protumačiti osobenostima datih domena odnosno činjenicom da domen sporta odlikuje veća fokusiranost na spoljnu realnost, dok domeni slikarstva i matematike podstiču introspektivnost i upućenost na intrapsihički plan, što prouzrokuje razlike u njihovoj emocionalnoj sferi. Veća zavisnost sportski darovitih pojedinaca od društvenog konteksta, doprinosi i njihovoj naglašenijoj socijabilnosti, dok uspešno ovladavanje domenom slikarstva ili matematike ne iziskuje naročitu otvorenost ka spoljnoj sredini. Naime, izgrađivanje reputacije $\mathrm{u}$ domenu sporta, pre svega, podrazumeva upućenost talentovanog pojedinca na segment njegovog društvenog okruženja označenog izrazom ,promoteri”, zbog čega je za ovaj vid darovitosti važna visoka razvijenost socijalnih veština, odnosno ovladanost ,pravilima igre” koja karakterišu domen sporta. Za razliku od toga, dostizanje visokog stepena 
razvijenosti likovnog ili matematičkog talenta, ne zahteva nikakvu ,promociju” te vrste, te je njihova aktualizacija zamisliva $\mathrm{i} u$ odsustvu visoke socijalne kompetencije.

Kada je u pitanju samosvest, iz Tabele 6 je uočljivo da se likovno daroviti učenici statistički značajno razlikuju od preostale tri grupe ispitanika, te da je ovo svojstvo kod njih najmanje izraženo. Iz iste tabele je uočljivo da grupa muzički darovitih učenika prednjači po izraženosti ovog svojstva (zatim slede sportisti, pa matematičari).

Tabela 6. Scheffe-ov test višestrukih poređenja među grupama (samosvest)

(I)

\begin{tabular}{|c|c|c|c|}
\hline Domen darovitosti & Domen darovitosti & $\begin{array}{l}\text { aritmetičkih sredina } \\
\text { I-J }\end{array}$ & $\mathrm{p}$ \\
\hline \multirow[t]{3}{*}{ Muzika } & Slikarstvo & $.509(*)$ & .004 \\
\hline & Sport & .021 & .999 \\
\hline & Matematika & .096 & .909 \\
\hline \multirow[t]{3}{*}{ Slikarstvo } & Muzika & $-.509(*)$ & .004 \\
\hline & Sport & $-.488(*)$ & .002 \\
\hline & Matematika & $-.413(*)$ & .022 \\
\hline \multirow[t]{3}{*}{ Sport } & Muzika & -.021 & .999 \\
\hline & Slikarstvo & $.488(*)$ & .002 \\
\hline & Matematika & .074 & .941 \\
\hline \multirow[t]{3}{*}{ Matematika } & Muzika & -.096 & .909 \\
\hline & Slikarstvo & $.413(*)$ & .022 \\
\hline & Sport & -.074 & .941 \\
\hline
\end{tabular}

Samosvest najbolje objašnjavaju ajtemi: „sposoban/na sam da utičem na druge”; „snalazim se u nepredviđenim, zahtevnim situacijama”; „živim u skladu sa svojim principima i vrednostima". Oslanjajući se na rezultate druge univarijantne analize varijanse, možemo zaključiti da likovno daroviti učenici pokazuju manje razumevanje sopstvenih osećanja, potreba, namera, vrednosti i slabosti, u odnosu na ostale ispitanike. Takođe, darovite u domenu slikarstva odlikuje slabije poznavanje vlastitih emocija i razumevanje njihovog dejstva, slabije poznavanje sopstvenih jakih i slabih strana, kao i niži nivo samopouzdanja. U vezi sa tim, ranija istraživanja su pokazala da likovno daroviti učenici pokazuju mnogo veće smetnje u aspektu socijalne prilagođenosti, najverovatnije zbog toga što društvo, te konsekventno i školski sistem, manje vrednuju darovitost u ovom domenu (Olenchak, 1999), što se verovatno negativno odražava i na njihovo samopouzdanje. S druge strane, izraženost ovog svojstva kod muzički darovitih učenika jasno ukazuje da je visoko vrednovanje vlastitih sposobnosti neobično važno za ovladavanje domenom muzike. S tim u vezi, Subotnikova i Džarvinova 
(Subotnik \& Jarvin, 2005) ističu važnost samopouzdanja na stepenu razvoja muzičkog talenta koji nadilazi nivo tehničke umešnosti, a poznata su i istraživanja predikcije uspešnosti u muzičkom izvođenju koja su istakla prediktivnu relevantnost doživljaja samoefikasnosti (McCormick, 2003).

\section{ZAKLJUČAK}

Sprovedenim istraživanjem ostvaren je izvestan doprinos $\mathrm{u}$ aspektu podrobnije deskripcije specifičnog kvaliteta različitih vrsta darovitosti. Uočava se da domen determiniše kvalitet darovitosti koja se u njemu manifestuje, te da se specifičnost tog kvaliteta ogleda kako u aspektu sposobnosti, tako i u aspektu emocionalnog funkcionisanja.

Nakon ispitivanja razlika između četiri grupe ispitanika pronađena su dva distinktivna obeležja u setu specifikovanih aspekata emocionalne inteligencije, a to su vladanje samim sobom i samosvest. Ovakvi rezultati upućuju na značaj domena u nastanku specifične konstelacije emocionalnih kompetencija koja se u njemu manifestuje. To ne znači nužno da domen oblikuje emocionalno funkcionisanje darovite osobe. Reč je o tome da veza između emocionalne inteligencije i domena $u$ kojem se manifestuje darovitost može biti dvosmerna: kao što postoji mogućnost da se određena ponašanja javljaju kao odgovor na zahteve domena, tako je moguće i da darovita osoba, pored izuzetne sposobnosti, poseduje i neke osobine koje je usmeravaju ka određenom domenu (Altaras, 2006). Konačno, nalazi o tome da darovitost podrazumeva različite konstelacije emocionalnih kompetencija $\mathrm{u}$ zavisnosti od vrste domena s kojim individua ostvaruje interakciju, upućuju na zaključak da se emocionalno funkcionisanje darovitih može precizno sagledati jedino ako se locira u okvire pojedinačnih domena.

$\mathrm{Na}$ kraju, značajno je istaći da svaki naučni rad koji se zasniva na kvantitativnoj metodologiji uključuje ograničenja koja proizilaze iz nesavršenih metoda procene relevantnih fenomena. U tom smislu, postavlja se pitanje da li bi primena nekog drugog instrumenata pružila drugačiju sliku o emocionalnoj inteligenciji učenika darovitih u različitim domenima. S tim u vezi, kao moguće ograničenje sprovedene studije prepoznaje se polje samoprocene ispitanika; uključivanje procene od strane drugih upotpunilo bi podatke o istraživanom fenomenu. Ipak, s obzirom na to da je pomenuta problematika kod nas nedovoljno istraživana, čini se da je studija poput ove predstavljala adekvatan korak. 
Milena M. Letić

\section{EMOTIONAL INTELLIGENCE OF GIFTED STUDENTS}

\section{Summary}

Starting from the modern understanding of giftedness as a domain-specific quality, which is not reflected only in the development of certain types of abilities, but also in various combinations of non-intellectual characteristics, an empirical study was conducted and aimed to complete the knowledge of the emotional sphere of gifted students in different domains. The aim of the research is to determine the distinctive characteristics of students gifted at music, art, sports and mathematics within the following aspects of emotional intelligence: self-awareness, self-regulation, social awareness and relationship management. A scale of emotional competences had been constructed for the needs of this research and was applied on a sample of 473 respondents, who attend specialized high schools for gifted students from Novi Sad, Belgrade and Kraljevo.

After examining the differences between the four groups of subjects, two distinctive features were found in a set of specific aspects of emotional intelligence, which are self-regulation and self-awareness. Self-regulation is most prominent among students gifted in sports and, accordingly, this group of respondents differs in a statistically significant way from the respondents gifted in art and mathematics. Such findings are explained by the specifics of given domains, i.e. by the fact that the domain of sport is characterized by a greater focus on external reality, while the domains of art and mathematics encourage introspectivity and an intrapsychic plan, causing differences in their emotional sphere. When it comes to selfawareness, it was noticed that artistically gifted students differ significantly from the remaining three groups of respondents, and that this feature is least pronounced in them. It is most prominent with musicians, followed by athletes and mathematicians. These findings have been linked to previous studies of similar issues that have shown that artistically gifted students show much more problems in the aspect of social adaptation, most likely because wider society, and consequently the school system, are less valued in this domain, which probably has a negative effect on their self-esteem. On the other hand, the expression of this characteristic in musically gifted students clearly indicates that the high evaluation of one's own abilities is crucially important for mastering the domain of music.

Overall, the results of the research indicate the importance of the domains of giftedness for the emergence of a specific constellation of the emotional competences that manifests itself within it. It is, therefore, concluded that the emotional functioning of gifted students can be accurately considered only if it is located within the frames of individual domains.

Keywords: non-intellectual characteristics, giftedness domains, self-awareness, selfregulation, social awareness, relationship management. 


\section{REFERENCE}

Altaras, A. (2006). Darovitost i podbacivanje. Pančevo: Mali Nemo.

Bouchet, N. \& Falk, R. F. (2001). The relationship among giftedness, gender, and overexcitability. Gifted Child Quarterly, 45(4), 260-267.

Caruso, D. R., Mayer, J. D. \& Salovey, P. (2002). Relation of an ability measure of emotional intelligence to personality. Journal of Personality Assessment, 79(5), 306-320.

Csikszentmihalyi, M., Rathunde, K. \& Whalen, S. (1997). Talented teenagers: The roots of success and failure. New York: Cambridge University Press.

Dabrowski, K. \& Piechowski, M. M. (1977). Theory of levels of emotional development: Multilevelness and positive disintegration. Oceanside, NY: Dabor Science.

Franks, B. \& Dolan, L. (1982). Affective characteristics of gifted children: Educational implications. Gifted Child Quarterly, 26(4), 172-177.

Gagné, F. (1997). Critique of Morelock's (1996) definitions of giftedness and talent. Roeper Review, 20(2), 76-85.

Gagné, F. (2005). From gifts to talents: The DMGT as a developmental model. In: R. J. Sternberg \& J. E. Davidson (Eds.), Conceptions of giftedness (pp. 98120). New York: Cambridge University Press.

Gardner, H. (1983). Frames of mind: The theory of multiple intelligences. New York: Basic Books.

Gardner, H. (1999). Intelligence reframed: Multiple intelligences for the 21st century. New York: Basic Books.

Gardner, W. L. \& Stough, C. (2002). Examining the relationship between leadership and emotional intelligence in senior level managers. Leadership and Organization Development Journal, 23(2), 68-78.

Goleman, D. (1995). Emotional intelligence: Why it can matter more than IQ. New York: Bantam Books.

Goleman, D. (1998). Working with Emotional Intelligence. London: Bloomsbury Publishing.

Goleman, D., Bojacis, R. \& Maki, E. (2006). Emocionalna inteligencija u liderstvu. Novi Sad: Adižes.

Heller, K. A., Perleth, C. \& Lim, K. (2005). The munich model of giftedness designed to identify and promote gifted students. In: R. J. Sternberg \& J. E. Davidson (Eds.), Conceptions of giftedness (pp. 147-170). New York: Cambridge University Press. 
Ilić, E. (2008). Emocionalna inteligencija i uspješno vođenje. Ekonomski pregled, 59(9/10), 576-592.

Lee, S-Y. \& Olszewski-Kubilius, P. (2006). The Emotional Intelligence, Moral Judgment, and Leadership of Academically Gifted Adolescents. Journal for the education of the gifted, 30(1), 29-67.

Letić, M. (2015). Značaj moralnih i liderskih svojstava za ostvarenje darovitosti. Neobjavljena doktorska disertacija, Novi Sad: Filozofski fakultet.

Mayer, J. D. \& Salvoley, P. (1993). The intelligence of emotional intelligence. Intelligence, 17(4), 433-442.

Mayer, J. D. \& Salovey, P. (1997). What is emotional intelligence. Emotional development and emotional intelligence. New York: Basic Books.

Mayer, J. D., Perkins, D. M., Caruso, D. R. \& Salovey, P. (2001). Emotional intelligence and giftedness. Roeper Review, 23(3), 131-137.

McClelland, D. C. (1998). Identifying competencies with behavioural-event interviews. Psychological Science, 9(5), 331-340.

McCormick, J. (2003). The role of self-efficacy in a musical performance examination: An exploratory structural equation analysis. Psychology of Music, 31(1), 37-51.

Norman, A. D., Ramsay, S. G., Martray, C. R. \& Roberts, J. D. (1999). Relationship between levels of giftedness and psychosocial adjustment. Roeper Review, 22(1), 5-18.

Olenchak, R. F. (1999). Affective development of gifted students with nontraditional talents. Roeper Review, 21(4), 293-300.

Palmer, B., Walls, M., Burgess, Z. \& Stough, C. (2001). Emotional intelligence and effective leadership. Leadership and Organization Development Journal, 22(1), 5-10.

Pekić, J. (2010). Uloga domena u nastanku specifičnog kvaliteta darovitosti. Godišnjak Filozofskog fakulteta u Novom Sadu, 35(1), 193-205.

Pekić, J. (2011). Karakteristike porodica sa akademski darovitim adolescentom. Neobjavljena doktorska disertacija, Novi Sad: Filozofski fakultet.

Piechowski, M. M. (1979). Developmental potential. In: N. Colangelo \& R. T. Zaffrann (Eds.), New voices in counseling the gifted (pp. 25-55). Dubuque, IA: Kendall/Hunt.

Piechowski, M. M. \& Colangelo, N. (1984). Developmental potential of the gifted. Gifted Child Quarterly, 28(2), 80-88.

Piechowski, M. M. \& Miller, N. B. (1995). Assessing developmental potential in gifted children: A comparison of methods. Roeper Review, 17(3), 176-180. 
Robinson, N. M. (2005). In defense of a psychometric approach to the definition of academic giftedness: A conservative view from a die-hard liberal. In: R. J. Sternberg \& J. E. Davidson (Eds.), Conceptions of giftedness (pp. 280-294). New York: Cambridge University Press.

Salvoley, P. \& Mayer, J. D. (1990). Emotional intelligence. Imagination, Cognition and Personality, 3(9), 185-211.

Sternberg, R. J. (2000). Wisdom as a form of giftedness. Gifted Child Quarterly, 44(4), 252-260.

Subotnik, R. \& Jarvin, L. (2005). Beyond expertise: Conceptions of giftedness as great performance. In: R. J. Sternberg \& J. E. Davidson (Eds.), Conceptions of giftedness (pp. 343-358). New York: Cambridge University Press.

Terman, L. M. (1925). Genetic studies of genius: Mental and physical traits of a thousand gifted children. Stanford, CA: Stanford University Press.

Winner, E. (1996). Gifted Children: Myths and Realities. New York: Basic Books. 